\title{
Renovation and reconstruction of universities
}

\author{
The first and foremost responsibility of a university is \\ to meet the needs of society
}

\section{Sanjay N Khanal}

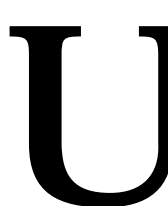

niversities can be characterized in terms of three philosophical missions. British universities and their derivativesfocus on thepursuit of truth, the development of intellectual capabilitiesand an atmosphere of profound academic freedom. Humboldt's university focuses on research and free exploration of truth, and their application. TheWisconsin model is based on service to society. Present-day universities, particularly in the developing world, should embraceall these concepts in their development and function. Major challenges to this objective include the brain drain, lack of funds, lack of tradition, and instability.

In addition to producingskilled professionals, universities should focus their academic programme and research initiatives on theneeds of their own societies, advancingscience and technology as part of the national developmental strategy at the same time as they conserve and promote their cultural and traditional heritages. Respected faculty, international student body, research of regional and global significance, service to thenational development agenda: thesearethecornerstones of a great university. A huge volume of resources, strong commitment and clear policies are required to mold and maintain high academic standards. Auniversity should foster an exchange of ideas at all levelsand incorporatea wide range of disciplines. Autonomy, both academic and administrative, is another core feature of the university. Freedom from government and other social institutions will generate effective performance. Self-governance could be ensured by outstanding performance, regular evaluations, and upgrading of standards. Decentralized and transparent decision-makinggeneratestrust in the university and facilitates development of functions suitable to local needs. Coordination among different schools, departments and colleges is needed to achieve the goals of the university. In the developing countries, this might bea difficult proposition. However, appropriate governing laws and financial freedom may help improve the situations. Institutions such as university grant commissions and academies may serve as buffer or lubricating mechanisms. Accreditation associations, academic or professional societies and other types of associations could be additional mechanismsto monitor and maintain academic standardsand academic autonomy. Allocation of development funds and scholarships from the government and international organizations will help strengthen the capacities of the universities.

Tolerance of critical thinking is essential. There should be no discriminations on any basis including differences of thinkingand doctrinesto pursuetruth among and between academic and administrative professionalsalong with thestudents. The freedom to the faculty to conduct research, to teach and to publish promotes and ensures the quality of theindividual institution and that of thesystem as a whole. Academic activities conducted in an easy, freeand open environment are invariably seen to produce better results. However, we must not forget that excessive freedom may lead to the breakdown of discipline and order.

Development of an international standard university is a long-term process achieved through a strategic plan. Equally important istheunderstanding of thesocieties about itsnatureand functions. Students, faculty, and staff aswell as government officials and citizens share equal responsibility. It is high timethat weall focus our energy on this endeavor.

Sanjay N Khanal is an associate professor at Department of Biological Sciences and Environmental Science, Kathmandu University, Dhulikhel, Kavre, Nepal.

E-mail: khanalsanjaynp@yahoo.com 